\title{
Technical Efficiency of Palm Oil Production in West Kalimantan
}

\author{
Ismiasih $^{*}$ \\ Jurusan Sosial Ekonomi Pertanian, Fakultas Pertanian, INSTIPER Yogyakarta, Jl. Nangka II, \\ Maguwoharjo, Sleman, DIY (0274) 885477, Indonesia
}

Received: 10 August 2017; Revised: 26 September 2017; Accepted: 22 November 2017

\begin{abstract}
This research aims to analyze the technical efficiency and source of technical inefficiency of palm oil production. The data used are secondary data from agricultural census survey in 2013 with a sample of 1229 farmer. Technical efficiency is measured by using stochastic frontier production function and is estimated using MLE method assuming that Cobb-Doughlas is the functional form of palm oil. From the research result, it is known that the factors that influence the technical efficiency of palm oil production in West Kalimantan Province are a number of productive trees, plant age, urea fertilizer, SP36, NPK, labor and dummy pesticide. Furthermore, variables of the percentage of own capital, membership of cooperative and membership of contract farming are influencing to reduce technical inefficiency. Therefore, efforts to improve the technical efficiency is to increase the role of the cooperative to its members, and increase the involvement of palm oil farmers in the plasma pattern.
\end{abstract}

Keywords: palm oil; stochastic frontier; technical efficiency; technical in-efficiency

\section{How to cite:}

Ismiasih. (2017). Technical Efficiency of Palm Oil Production in West Kalimantan. HABITAT, 28(3), 9198. https://doi.org/10.21776/ub.habitat.2017.028.3.13

\section{Introduction}

Palm oil (Elaeis guineensis) is one of the commodity crops in Indonesia. Palm oil production makes Indonesia a supplier of approximately half of the world's palm oil supply. Therefore it encourages Indonesian community economy. Aside from being a producer of palm oil and palm kernel, the palm tree is also a source of non-oil and gas income, farmers' income, job creation, agribusiness and agro-industry activities in the region and regional development. The bright prospect of palm oil commodities in vegetable oil trade field has prompted the Indonesian government to spur the increase of palm oil exports and become the major producer of Crude palm oil in the world.

Crude palm oil (CPO) produced from palm trees has many advantages compared to other vegetable oils. These are long-lasting, resistant to pressure, and have relatively high-temperature tolerances. In addition, palm oil also has many advantages including 1) the utilization of palm oil is very broad in food and non-food categories. 2)

*Corresponding Author:

E-mail: ismiasih77@yahoo.com palm oil productivity reached 3.2 tons/ha while soybean, radish, copra and sunflower oils were only $0.34 ; 0.51 ; 0.57$; and 0.53 tons/ha (Fauzi, 2012).

Therefore, the development and expansion of palm tree plantations in Indonesia are increasing annually. There are three main forms of palm oil plantation in Indonesia: Public Plantations (PR), Large Private Plantations (PBS), and Large State Plantations (PBN). Although faced with various obstacles, Pelita I endeavors to conduct area expansion and increase palm oil production in Indonesia which continues to take place at a rapid pace (Mangunsoekarjo, 2003).

According to data taken from the Directorate General Ministry of Agriculture Indonesia, the total area of palm tree plantations in Indonesia 2015 reached about 11.3 million hectares. 4.58 million hectares $(40.53 \%)$ owned by community plantations (PR), 750 thousand hectares (6.64\%) Large State Plantations and 5.97 million hectares $(52.83 \%)$ are large private plantations (PBS). This number is expected to increase to 13 million hectares by 2020 . This figure exhibits palm tree plantations in Indonesia tends to increase every year. In general, palm oil tree area in Indonesia tended to increase with an 
average growth of $11.12 \%$ in the 1970-2009 period (BPS, 2014).

In line with the increasing palm oil tree plantations area, Indonesia's palm oil production (CPO) has also increased. Indonesia's palm oil production in 2009 was 21.39 million tons and is expected to increase to 29.34 million tons in 2014. Based on its concession status, large private plantations produce palm oil (CPO) around 15.63 million tons which are 56.25 percent of the national $\mathrm{CPO}$ production. Meanwhile, CPO production by large state plantations and smallholders is 2.16 million tons and 10.6 million tons or 7.34 percent and 36.41 percent respectively of total national $\mathrm{CPO}$ production (BPS, 2014).

Public palm oil tree plantation experienced large growth rate since the implementation of the Perusahaan Inti rakyat Perkebunan or Core Estate and Smallholder for Plantation (PIR-BUN) program in 1980. Large estates as the core nurture and accommodate the yield. The community plantation is the plasma garden (palm oil tree plot). Plantation expansion became more widespread with the establishment of the Perusahaan Inti Rakyat Transmigrasi or Core Estate and Smallholder for Transmigration (PIRTrans) in 1986 to 1990 . In this case, the core plantation is managed by private estates and plasma plantations owned by transmigrated residents, including local transmigrants.

Through this program, investment of palm oil plantations is growing rapidly. Plantation land procurement is supported by the government. Funds procurement is supported by banks. In addition, the expansion of public palm oil plantations was caused by new rules for large plantations land expansion and the increasingly limited land clearing and large palm oil cultivation. The reality on the field exhibits that public plantations are faced with many limitations. The existence of limited resource ownership and access to public plantations makes farmers more likely to manage their palm oil not in accordance with existing technical recommendations.

Large plantations on the other hand, both state and private, can easily gain access to capital, plantation resources, and human resources. Large plantations can manage plantations according to technical recommendations using their capital advantage. They are capable of obtaining best technology to be used on the plantation. This leads to greater plantation productivity compared to public plantations.
Therefore, one of the endeavor to bridge the gap of access and resources between smallholders and large plantations is through a partnership arrangement by placing large plantations as nucleus and smallholder estates as plasma. The partnership will improve the productivity and quality of community plantation. It is expected to maintain the quantity, quality, and continuity of raw material supply for the industry.

Basically, the plantation is formed to gain big profit. According to Soekirno (2002), within economic theory, there is no existing difference between government and private companies in terms of goals. All types of companies as business units possess similar goal is to achieve maximum profit. To achieve maximum profit, the company must be efficient. It is said to be efficient when the output (output) achieved is higher than the input (input) used.

Soekartawi (1991) indicates that the production process is considered to be efficient if limited resources can be utilized optimally to produce optimal output. However, producers often incapable to achieve the target (potential production). This indicates that the utilization of production factors has not been maximized resulting in the less efficient production process so that the resulting product does not reach the target.

Azzuhdan research (2014) on technical efficiency of CPO production at PT. Windu Nabatindo Abadi, Kotawaringin Timur with DEA (Data Envelopment Analysis) method states that CPO production has not run efficiently. The average value of economic efficiency (technical efficiency, price efficiency) has not been able to achieve full efficient conditions because the resulting efficiency value is merely 0.90 . This is caused by frequent shortages of FFB (Fresh Fruit Bunches), therefore CPO production cannot be maximized. There is a shortage of machinery that causes reduce CPO production effective time. Factors that significantly affect the production of $\mathrm{CPO}$ are Fresh Fruit Bunches (TBS), CaCO, Soda Ash, and Labor.

A similar phenomenon occurred in Utami's study (2013) on the analysis of production efficiency at the palm oil processing plant in PT. Gersindo Regency of West Pasaman. It concluded that the factors influencing CPO production result are fresh fruit bunches, chemicals, and labor force. Therefore so it is advisable on the part of the company to be able to increase the use of its FFB production factor up to factory's capacity.

West Kalimantan Province is one of the largest palm oil suppliers in Kalimantan Island Available online at HABITAT website: http://www.habitat.ub.ac.id ISSN: 0853-5167 (p); 2338-2007 (e) 
with the potential land acquisition for plantation. It is evident that the land cultivated for palm oil plantations in 2014 is about 936,407 hectares with an average production of 1,965,515 tons. With the wide area cultivated by the public plantation is 492,993 tons with an area of 339,866 ha, State Plantation with an average production reaches 125,090 tons with an area of 56,205 ha, and private plantations with an average production of $1,347,432$ tons with an area of 540,336 ha (Ditjenbun, 2016). The production of palm oil in West Kalimantan Province exhibited a significant increase and is likely to increase every year. This is due to the increasing demand for palm oil in the world. However viewed from the production of palm oil according to enterprise status, public plantation still under private companies. This is likely because private plantations can easily gain access to technology, capital, human resources, natural resources, and supported by sound management. Therefore private plantation productivity is higher than the public plantations. The efficiency level of the private plantation is better than the public plantation.

Efficiency can be used as a measure of the extent of production system applied economic principle on the manner to produce a certain output level using minimal input or how to produce the product as closely as possible using a certain amount of input. Therefore it is necessary to plan more appropriately in allocating the owned production factors to produce maximum output. Technical efficiency can be achieved which is characterized by optimal CPO production and efficient prices are also achieved which is characterized by producers success in obtaining maximum profit.

Based on the background and the formulation of the problem, this research aims to: 1) determine the technical efficiency level of public palm oil production and the factors that influence it and 2) determine the factors affecting the technical inefficiency on palm oil production in West Kalimantan Province.

\section{Research Method}

The study was conducted in West Kalimantan Province considering that the province is the largest producer of palm oil in Kalimantan Island, with the production of $1,965,515$ tons with an area of 936,407 ha (Ditjenbun, 2016). The data used in the research is secondary data obtained from the results of agricultural census in 2013 with a sample of 1229 farmers.

Analysis of technical efficiency and determinants of technical inefficiency used stochastic production function Frontier (SPF). This function was first introduced by Aigner et al (1977); Meeusen and Van den Broek (1977), Battese and Coelli (1988). In this research the stochastic frontier production function is assumed to be in Cobb-Doughlas linear form of natural logarithm which is described as follows:
$\operatorname{Ln} \mathrm{y}=\beta_{0}+\beta_{1} \ln \mathrm{X}_{1}+\beta_{2} \ln \mathrm{X}_{2}+\beta_{3} \ln \mathrm{X}_{3+} \beta_{4} \ln \mathrm{X}_{4}+$ $\beta_{5} \ln \mathrm{X}_{5}+\beta_{6} \ln \mathrm{X}_{6+} \delta_{1} \mathrm{D}_{1}+\delta_{2} \mathrm{D}_{2}+\delta_{3} \mathrm{D}_{3}+$ (Vi-Ui)

$\mathrm{Y}=$ Palm oil production (ton)

$\mathrm{X} 1=$ Total productive plant (tree)

$\mathrm{X} 2=$ Plant age (year)

$\mathrm{X} 3=$ Urea fertilizer $(\mathrm{kg})$

$\mathrm{X} 4=\mathrm{SP} 36$ fertilizer $(\mathrm{kg})$

$\mathrm{X} 5=\mathrm{NPK}$ fertilizer $(\mathrm{kg})$

$\mathrm{X} 6=$ workforce $(\mathrm{HOK})$

$\mathrm{D} 1=$ pesticide dummy

D2 = climate dummy

D3 = peatlands dummy

$\beta_{0}=$ intersep

$\mathrm{Vi}-\mathrm{Ui}=$ error term $(\mathrm{ui}=$ technical efficiency effect in the model)

The level of technical efficiency (ET) for each individual is obtained from the comparison between the actual level of output (Yi) with the predicted output level, exp (Xi, $\beta)$. To determine value of distribution parameter $(\mu \mathrm{i})$ effect of technical inefficiency in this research, the following formula was used:

$\mu_{\mathrm{i}}=\delta_{0}+\delta_{1} \ln \mathrm{z}_{1}+{ }_{+} \delta_{2} \ln \mathrm{z}_{2}+\delta_{3} \ln \mathrm{z}_{3}+\delta_{4} \ln \mathrm{z}_{4}+\delta_{5} \ln$

$\mathrm{z}_{5}+\delta_{6} \ln \mathrm{z}_{6}+\delta_{7} \ln \mathrm{z}_{7}$

$\mu_{\mathrm{i}=}$ technical inefficiency effect

$\ln \mathrm{z}_{1}=$ farmer age (year)

$\ln z_{2}=$ farmer education level (year)

$\ln \mathrm{Z}_{3}=$ personal capital ownership percentage (percentage)

$\ln \mathrm{z}_{4}=$ counseling participation

$\ln \mathrm{Z}_{5}=$ cooperative membership

$\ln \mathrm{Z}_{6}=$ farmer union membership

$\ln \mathrm{z}_{7}=$ plasma farmer

$\delta_{0}=$ intercept

$\delta_{1-} \delta_{7}=$ predictor coefficient parameter

The model parameter estimation was calculated using Maximum Likelihood Estimates (MLE) in the form of computerized program Fontier version 4.1 developed by Coelli (1996). The determination of efficiency level distribution 
is made based on previous research (Ogundari and Ojo, 2007), by dividing the efficiency level into the following:
a) Very efficient: TE $\geq 0,90$
b) Moderately efficient : 0,70 $\leq \mathrm{TE}<0,90$
c) Not efficient : TE $<0,70$

\section{Findings and Discussion}

The production function exhibited the maximum number of outputs that can be achieved by combining the various number of inputs. Thus a production function is said to be Frontier if it describes the level of outermost production that can be produced by the use of certain inputs. The purpose of production function analysis is to analyze the factors affecting the function of palm oil production in West Kalimantan Province. The production function model used is a functional model of stochastic production frontier CobbDouglas using Maximum Likelihood Estimation (MLE) parameter. The reason for using the MLE method to illustrate the relationship between maximum production that can be achieved with the factors of production used.

In this research, 9 independent variables of production function predictor are total productive plants (x1), plant age (x2), Urea fertilizer (X3), SP36 (x4), NPK (x5), use of manpower (X6) pesticides (D1), climate (D2), and peatland (D3).

The estimation result of stochastic frontier production function is exhibited in Table 1.

Table 1. Real Production Function of Palm Oil in West Kalimantan Province

\begin{tabular}{lll}
\hline Var. & Koef & t-ratio \\
\hline Coef. & 1,98 & $23,71^{* * *}$ \\
Productive plant & 0,75 & $21,36^{* * *}$ \\
Plant age & 0,48 & $11,62^{* * *}$ \\
urea & 0,01 & $3,66^{* * *}$ \\
SP36 & 0,02 & $4,63^{* * *}$ \\
NPK & 0,01 & $3,45^{* * *}$ \\
TK & 0,07 & $1,92^{* *}$ \\
Pesticide & 0,04 & $2,08^{* * *}$ \\
Climate & $-0,05$ & $-1,46^{*}$ \\
Peatlands & $-0,01$ & $-0,44^{\text {ns }}$ \\
Sigma square & 0,09 & \\
log likelihood funct. & $-265,09$ \\
***real at $\alpha 1 \%$ & \\
** real at $\alpha$ 5\% & \\
* real at $\alpha 10 \%$ & \\
ns non-significant & \\
\multicolumn{3}{l}{ In Table 1. all variables are significantly } \\
different to palm oil production, except for \\
peatland which has no significant effect on palm
\end{tabular}

oil production. A total productive plants variable have a positive and significant effect on the amount of palm oil production. The coefficient value on the total productive plants was 0.75 , it indicates $1 \%$ increase in the total productive plants would increase palm oil production by $0.75 \%$.

Plant age variable has a positive and significant effect on palm oil production. The coefficient value of plant age is 0.48 , it indicates $1 \%$ additional plant age of $1 \%$ would increase palm oil production by $0.48 \%$. Therefore older plants would increase palm oil production.

The use of Urea fertilizer significantly affects the production of palm oil. Variable coefficient equal to 0,01 , indicates increasing $1 \%$ urea fertilizer equal would increase palm oil production up to $0,01 \%$. Similarly, the use of SP 36 and NPK fertilizers, each coefficient possess positive and significant effect on palm oil production. Therefore increasing SP 36 and NPK fertilizer amount would increase production.

The coefficient of labor variable is positive and significant, with a coefficient equal to 0,07 , it means that if there is an increase of labor by $1 \%$ it will increase palm oil production by $0,07 \%$. Additional efforts can be made by increasing the number of workers or by adding work hour.

Dummy pesticide variable coefficient was positive and possess a significant effect on palm oil production. This indicates that pesticide fertilizer utilization would increase the amount of palm oil production

Dummy variable of climate change impact is negative and has a significant effect on the amount of palm oil production. This indicates that in the production of palm oil is affected by climate change, its value is less than that of palm oil which is not affected by climate change.

The peatland variable coefficient is negative and has no significant effect on palm oil production. This indicates that palm oil trees planted on peatlands and other cultivated land have no effect on palm oil production.

Technical efficiency analysis was conducted using stochastic frontier production function model with Frontier 4.1 program. The distribution of the technical efficiency on public palm oil production is shown in Table 2 . The efficiency index value of the analysis results can be categorized as efficient should production input value approaches 1 . The category used is said to be very effective if it has a value of 0.90 and above, moderately efficient if the value is between 0.70 up to 0.89 and not efficient if the value is less than 0.70 . 
Table 2. Distribution of Public Palm Oil Technical Efficiency in West Kalimantan Province

\begin{tabular}{lcc}
\hline \multicolumn{1}{c}{ Technical } & \multicolumn{2}{c}{ Total Farmer } \\
\cline { 2 - 3 } Efficiency Group & Palm Oil & Percentage \\
\hline$<0,70$ & 145 & 11,79 \\
$0,70 \leq \mathrm{TE}<0,90$ & 699 & 56,88 \\
$\geq 0,90$ & 385 & 31,33 \\
\hline Total & 1229 & $100 \%$ \\
\hline Average TE & 0,83 & \\
Maximum TE & 0,97 & \\
Minimum TE & 0,19 & \\
\hline
\end{tabular}

The average technical efficiency gained is 0.83 , it indicated that the productivity of palm oil plantations in West Kalimantan Province has reached 83 percent of the maximum productivity that can be achieved. The highest technical effisineis reached 97 percent and the lowest efficiency was 19 percent.

Based on distribution of technical efficiency value described in Table 2, the majority of palm oil farmers in West Kalimantan Province or 699 farmers $(56.88 \%$ ) has an efficiency value in the range of 0.70 to 0.90 . This indicates that farmers could increase productivity up to $10 \%$. Farmers who are categorized as very efficient $(>0.90)$ or have a chance to increase the productivity of $<10 \%$ was around 385 farmers $(31.33 \%) .145$ farmers $(11.79 \%)$ are in not efficient category $(<0.70)$.

Based on the distribution of technical efficiency, palm oil farmers in West Kalimantan Province are technically efficient farmers with an efficiency value range between 0.70 and 0.90 , however, there is a need to increase managerial efforts to achieve very efficient category. This could be achieved by improving the skills and techniques in cultivation as conducted by technically efficient farmers.

This result is in accordance with Junaedi research (2016) which describes the technical efficiency of cotton farmers in South Sulawesi. The majority is technically inefficient possessing efficiency value below 70 with a range of 0.50 0.69 with an average technical efficiency equal to 0.65. A similar result was encountered in Proyoga's research (2010), which states that the technical efficiency level of organic rice farmers in Central Kalimantan varies from 0.47 to 0.96 with an average value 0.70 .

Factors affecting the technical efficiency of palm oil production are analyzed using the technical inefficiency effect model of the stochastic frontier production function. Analysis results can be seen in Table 3 .

Table 3. Stochastic Frontier Production Function of Public Palm Oil in West Kalimantan Province using MLE Method

\begin{tabular}{|c|c|c|}
\hline var & koefisien & t-ratio \\
\hline Constant & 2,64 & $31,68 * * *$ \\
\hline \multicolumn{3}{|l|}{ Total productive } \\
\hline $\begin{array}{l}\text { plant } \\
\text { Plant age }\end{array}$ & $\begin{array}{l}0,14 \\
0,10\end{array}$ & $2,27 * * *$ \\
\hline Urea & 0,01 & $3,20 * * *$ \\
\hline SP36 & 0,01 & $3,71 * * *$ \\
\hline NPK & 0,01 & $3,65 * * *$ \\
\hline Workforce & 0,08 & $2,34 * * *$ \\
\hline Dummy pesticide & 0,04 & $2,10 * * *$ \\
\hline Climate dummy & 0,01 & $0,42^{\text {ns }}$ \\
\hline Peatlands dummy & 0,01 & $0,67^{\text {ns }}$ \\
\hline \multicolumn{3}{|l|}{ MLE } \\
\hline Log- & \\
\hline $\begin{array}{l}\text { likelihood } \\
\text { function }\end{array}$ & \multicolumn{2}{|l|}{163,05} \\
\hline LR test & \multicolumn{2}{|l|}{204,07} \\
\hline $\begin{array}{l}\text { Mean level } \\
\text { efficiency }\end{array}$ & \multicolumn{2}{|l|}{0,83} \\
\hline $\begin{array}{l}\text { Sigma- } \\
\text { square }\end{array}$ & \multicolumn{2}{|c|}{$2,42 * * *$} \\
\hline gamma & 0,96 & $62,86 * * *$ \\
\hline
\end{tabular}

$* * *$ real at $\alpha 1 \%$

${ }^{\mathrm{Ns}}$ non-significant

Based on the estimation of stochastic frontier production function Table 3., this model has $\gamma$ parameter equal to 0,96 . The alleged parameter $\gamma$ represents the ratio between the inefficiency deviation and the technical deviation that may be caused by a random factor. Statistically the value of 0.96 means that $96 \%$ of the errors in the production function illustrate the farmer's technical efficiency due to technical inefficiency, which means that existing error was not caused by random error variables or stochastic effects such as weather, pests and model errors.

Based on Table 3 analysis result, variables possessing positive and significant effect are the total productive plants, plant age, urea fertilizer, SP 36, NPK, labor and dummy pesticides. While the variables that have no effect on palm oil production are dummy impacts of climate change and dummy peatlands.

Factors influencing the level of farmers' technical efficiency were analyzed using the technical inefficiency effect model of the stochastic frontier production function. The 
alleged parameters of technical inefficiency can be seen as Table 4.

Table 4. Factors Affecting Technical Inefficiency in Oil Palm Plantation West Kalimantan Province

\begin{tabular}{lcc}
\hline Variable & $\begin{array}{l}\text { Coefficie } \\
\text { nt }\end{array}$ & t-ratio \\
\hline Constant & $-2,65$ & $-1,85 * *$ \\
Farmer age & 0,01 & $1,99 * * *$ \\
Farmer education level & 0,21 & $2,25 * * *$ \\
Capital ownership & $-0,01$ & $-2,04 * * *$ \\
$\begin{array}{l}\text { Counseling } \\
\text { Participation }\end{array}$ & 0,64 & $2,35 * * *$ \\
$\begin{array}{l}\text { Cooperative } \\
\text { Membership }\end{array}$ & $-4,51$ & $-2,38 * * *$ \\
$\begin{array}{l}\text { Gapoktan farmer } \\
\text { union) membership }\end{array}$ & 0,67 & $2,77 * * *$ \\
Plasma farmer & $-1,40$ & $-2,31 * * *$ \\
\hline$* * *$ real at $\alpha 1 \%$ & & \\
$* *$ real at $\alpha 5 \%$ & &
\end{tabular}

Based on the estimation of the technical inefficiency effect model (Table 4), the inefficiency variables used were farmer age, farmer education level, the percentage of capital ownership, counseling participation, cooperative members, gapoktan (farmer union) members, and involvement as plasma farmer. These variables have a significant effect on palm oil production. It is expected that these variables will be negative therefore each variable can reduce inefficiency or increase the technical efficiency of palm oil production.

Significantly negative variables affecting technical inefficiency of palm oil production are a percentage of capital ownership, cooperative membership, and involvement as plasma farmer. This indicates that the three variables have a positive effect on the farmers' technical efficiency in increasing the production of palm oil. Therefore should total ownership of capital, level of cooperative member and plasma farmer/ smallholders increases, the level of technical efficiency will increase. In other words, it can reduce the level of technical inefficiency in production Palm oil.

Farmers age, education level, participation level in counseling and gapoktan membership have a positive and real effect on the technical inefficiency of palm oil public plantation. This indicates that farmer age, education level, counseling participation, and gapoktan membership increase, it will increase technical inefficiency or in other words will reduce the level of technical efficiency.

The age variable has a positive but very small effect on technical inefficiency, with a positive coefficient. This indicates older farmers would increase technical inefficiency in production. In other words, younger farmers are more efficient.

Formal education has a positive effect on inefficiency. This indicates that the higher the level of education the inefficiency will be greater. Occupation as a palm oil farmer is a tough job that does not take into account the latest education, the most important is having a passion for working and having a strong physical capability.

Ownership of capital has a negative effect on technical inefficiency. This indicates that the greater the capital itself will decrease technical inefficiency or in other words will further improve the technical efficiency. This is because the farmers think that using personal capital would manage the plantation better.

Counseling participation is marked positive on technical inefficiency. Counseling obtained by farmers result in greater technical inefficiency. This can be due to counseling material provided not in accordance with farmers need at the time or the farmers think they are more experienced than counseling workers, therefore, counseling material is considered inappropriate.

Cooperative membership has a negative and real effect on technical inefficiency. Membership in the cooperative has the effect of reducing the level of technical inefficiency or improving the technical efficiency of farmers production level. Cooperative member possess many benefits, especially in the ease of meeting the needs of facilities and infrastructures, therefore, farmers can improve productivity.

Gapoktan (farmer union) membership has a positive and significant effect on technical inefficiency. This indicates that membership in farmer group results in technical inefficiency or decreases technical efficiency. This is because farmers are more comfortable with cultivation techniques that are commonly done, so participation in farmer groups is considered to be of no benefit. This is similar Suprapti's finding (2017) in corn crops in Sumenep, Andarwati's research (2011) in potato plants in Banjarnegara and Ekanintias's study (2011) on Japanese spinach plants in West Java, indicating that involvement as farmer group members does not guarantee more efficient farming. 
Involvement as plasma farmer variable has a negative and real effect on technical inefficiency. This condition is in line with the government's expectation that the involvement of farmers in the plasma program will facilitate farmers in obtaining access to capital and resources in an endeavor to increase productivity.

\section{Conclusion}

Based on the results of the analysis and discussion, it can be concluded that:

a. The average technical efficiency of palm oil farmers in West Kalimantan Province is technically moderately efficient.

b. Factors that provide positive and real influence on technical efficiency of palm oil production in West Kalimantan Province total productive crops, plant age, urea fertilizer, SP36, NPK, labor, and dummy pesticides.

c. Factors that have a positive and real effect on technical inefficiency are farmer age, farmer education level, counseling participation, and gapoktan membership (farmer union)

d. Factors that have a negative and real impact on technical inefficiency are percentage of personal capital, membership in cooperatives, and involvement as a plasma farmer.

Based on the conclusion, endeavor to be made to improve technical efficiency of palm oil production in West Kalimantan Province and lower the level of inefficiency are described as follows:

Farmers should increase the total productive plants or rejuvenate the crops that cease production with productive crops (replanting).

In order to increase the production of palm oil, the farmers should increase the amount of fertilizer and labor use.

Encourage palm oil farmers to join cooperative members and plasma farmers program.

\section{Daftar Pustaka}

Aigner, D.J., C.A.K. Lovell and P. Schmidt. (1977). Formulation and Estimation of Stochastic Frontier Production Function Models. Journal of Econometrics, 6 (1): 2137.
Azzuhdan dkk., (2014). Analisis Efisinesi Ekonomi Produksi Crude Palm Oil (CPO) di PT Windu nabatindo Abadi, Kabupaten Kotawaringin Timur. Jurnal Habitat . 25 (3).

Battese, G. E., and T. J. Coelli. (1988). Prediction of Firm-Level Technical Efficiencies with A Generalized Frontier Production Function and Panel Data. Journal of Econometrics, 38 (1988): 387-339.

BPS. (2014). Stasik Perkebunan. Direktorat Jenderal Perkebunan Kementerian Pertanian.

Coelli, T. J. (1996). A Guide to Frontier Version 4.1: A Computer Program for Stochastic Frontier Production and Cost Function Estimation. Centre for Efficiency and Productivity Analysis, University of New England -Armidale, New South Wales.

Ditjenbun. (2016). Statistik Perkebunan Indonesia Komoditas kelapa sawit 2014-2016.

Fauzi, Y., dkk. (2012). Kelapa sawit: Budidaya, Pemanfaatan Hasil dan Limbah, Analisis Usaha dan Pemasaran, Jakarta : Penebar Swadaya.

Junaedi. (2016). Pengembangan Kapas Rakyat di Sulawesi Selatan : Kajian Terhadap Efisiensi Produksi dan Daya Saing. Mujahid. Bandung.

Mangunsoekarjo, S, H. (2003). Manajemen Agribisnis Kelapa Sawit. Gadjah Mada University Press. Yogyakarta.

Meeusen, W., and J. V. D. Broeck. (1977). Efficiency Estimation from Cobb-Douglas Production Function with Composed Error. International Economic Review, 18 (June 1977) : 435-444.

Ogundari K., and S.O. Ojo. (2006). An Examination of Technical, Economic and Allocative Efficiency of Small Farm: The Case Study of Cassava Farmers in Osun State of Nigeria. Journal Central European Agriculture, 7(3) : 423-432.

Soekirno, S. (2002). Pengantar Teori Mikroekonomi. Jakarta : PT Raja Grafindo Persada.

Soekartawi. (1991). Agribisnis : Teori dan Aplikasi. PT Raja Grafindo Persada. Jakarta. 
Suprapti. (2017). Efisiensi Produksi dan Perilaku Petani Terhadap Resiko Produksi Jagung Hibrida dan jagung Lokal di Kabupaten Sumenep. Disertasi Program Pasca Sarjana. Fakultas Pertanian. Universitas Gadjah Mada. Yogyakarta.

Utami, S. (2013). Analisa Efisiensi Produksi pada pabrik Pengolahan Kelapa sawit di PT. Gersido Miinang Plantation Kabupaten Pasaman Barat. Skripsi. Program Studi Agribisnis. Universitas Andalas. 